\title{
Magmatic and metamorphic events recorded within the Southwestern Basement Province of Svalbard
}

\author{
Jarosław Majka ${ }^{1,2} \cdot$ Karolina Kośmińska²
}

Received: 11 August 2017 / Accepted: 22 November 2017 / Published online: 28 November 2017

(c) The Author(s) 2017. This article is an open access publication

\begin{abstract}
A recent increase in fieldwork activity within the Southwestern Basement Province (SBP) of Svalbard followed by detailed geochronological and petrological studies has allowed recognition of previously unknown magmatic and metamorphic events in the studied region. These discoveries of, e.g. true c. $950 \mathrm{Ma}$ granitic magmatism, c. $640 \mathrm{Ma}$ Torellian metamorphism, completely new localities of high-pressure rocks and a c. 360 Ma Ellesmerian, Barrovian-type metamorphic sequence emphasize the importance of further research in this part of the Svalbard Archipelago. Paleogene tectonic overprint of the SBP, manifested by the West Spitsbergen Fold and Thrust Belt, is an additional challenge for geologists working in this part of Svalbard's crystalline basement, and must be taken into account in all interpretations of pre-Cenozoic structures. Several enigmatic issues concerning the evolution of the SBP remain unanswered. Hence, there is a need for continued research in this key area for understanding the geological evolution of the northern Barents Shelf and High Arctic in general.
\end{abstract}

Keywords Caledonides $\cdot$ Magmatism $\cdot$ Metamorphism $\cdot$ Spitsbergen $\cdot$ High Arctic

\section{Introduction}

The crystalline Caledonian basement of Svalbard is divided into three provinces, namely Northeastern, Northwestern and Southwestern ([10, 15]; Fig. 1). The Northeastern and Northwestern provinces are, according to a tectonic model, separated by major $\mathrm{N}-\mathrm{S}$ trending strike-slip fault zones [20]. The boundary of the Southwestern and Northwestern provinces is hidden under the front of the Paleogene West Spitsbergen Fold and Thrust Belt, whereas the contact of the Southwestern and Northeastern provinces does not crop out and it is only hypothesized to be, per analogy, a strike-slip tectonic zone (e.g. [15]). This paper focuses on the Southwestern Basement Province (SBP; Fig. 1), a part

This article was selected from the third Circum-Arctic Structural Event workshop which was held in Hannover (Germany) in March 2017.

Jarosław Majka

jaroslaw.majka@geo.uu.se

1 Department of Earth Sciences, Uppsala University, Villavägen 16, 75236 Uppsala, Sweden

2 Faculty of Geology, Geophysics and Environmental Protection, AGH-University of Science and Technology, al. Mickiewicza 30, 30-059 Kraków, Poland of Svalbard's crystalline basement which bears record of multiple magmatic and metamorphic events, some of which are unknown elsewhere within the archipelago. The recent attempts to recognize these events have provided sufficient amounts of new data to justify this short summary.

The SBP records a sequence of magmatic and metamorphic events spanning from the Mesoproterozoic to Devonian. The oldest magmatism recorded within the SBP is of Stenian-Ectasian age $[3,4,28]$ and comprises a continental rifting-related suite of rocks [8] that only occur locally in the southern part of the SBP. Similarly, occurrences of Tonian igneous rocks are very limited as, to date, they are only known from two localities in Wedel Jarlsberg Land and Oscar II Land [12, 32]. Both Stenian-Ectasian and Tonian igneous rocks (at least in the southern part of the SBP), as well as associated amphibolite facies metasedimentary successions, were affected by Late Neoproterozoic Torellian metamorphism (e.g. [29, 32]). The Torellian Orogeny is also manifested in the form of a regional-scale angular unconformity [6, 7], which divides substantially folded, but weakly metamorphosed, Early Neoproterozoic metasediments from overlying Late Neoproterozoic and less deformed metasediments. These Early Neoproterozoic lowgrade metasediments are intruded by a mafic dyke swarm, whereas the low-grade Late Neoproterozoic metasediments 
Fig. 1 Geological map of southwestern Svalbard [10, modified]. The units and localities mentioned in the text are marked on the map

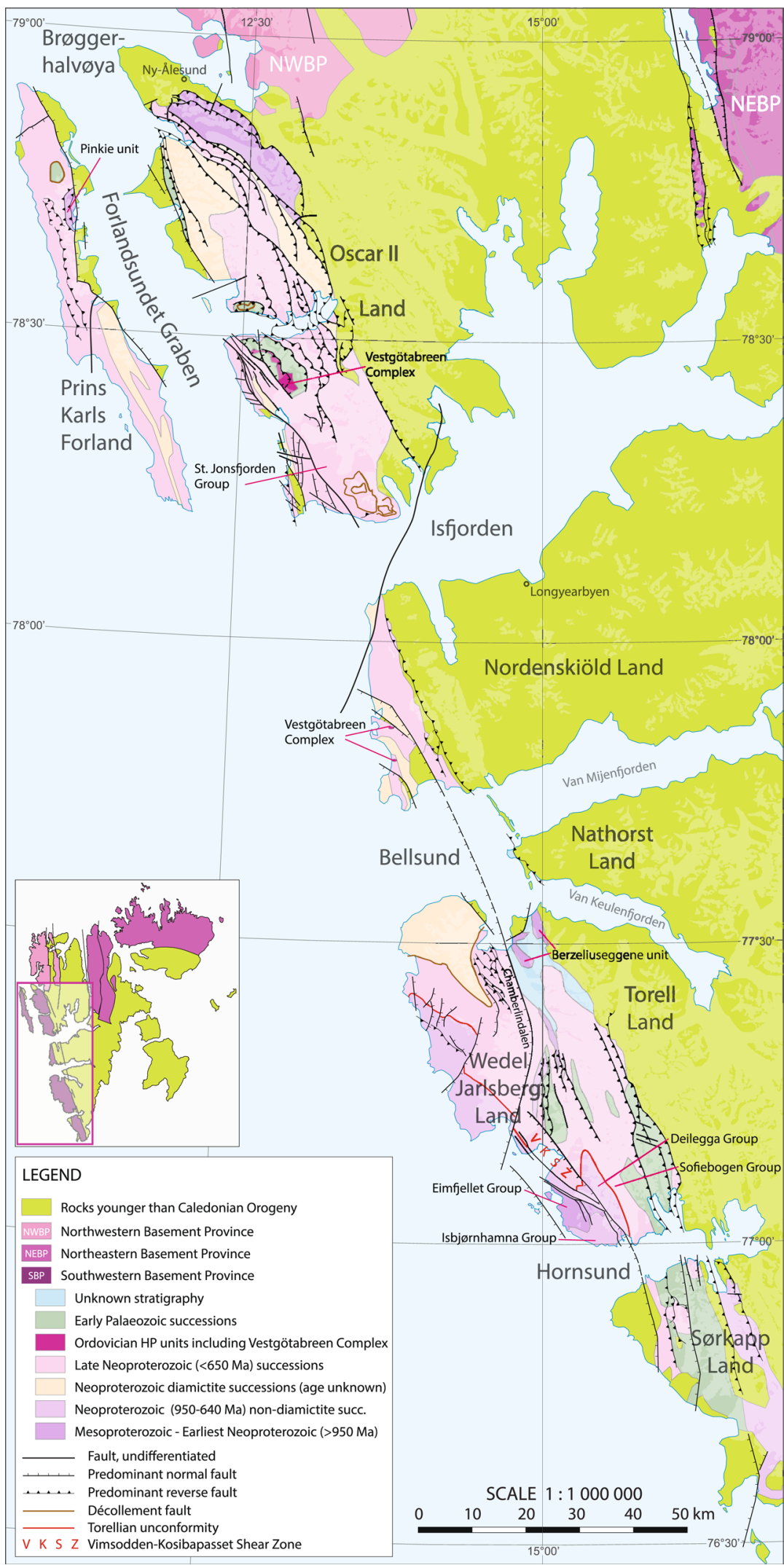


above the Torellian unconformity are intercalated with the extrusive equivalents of the mafic dyke swarm [8]. All of the aforementioned units have been subsequently folded and metamorphosed under greenschist facies conditions during the Caledonian Orogeny (e.g. [10]). However, the SBP also bears record of subduction-related Caledonian metamorphism of blueschist to eclogite grade (e.g. [25, 33, 36]). These high-pressure (HP) rocks in their type locality at Motalafjella are unconformably overlain by a Late Ordovician to upper Silurian sedimentary succession [2, 43]. Finally, a clearly exotic Barrovian-type sedimentary sequence that was metamorphosed during the Late Devonian Ellesmerian Orogeny has been recently described from the westernmost part of the SBP [26, 27]. The Ellesmerian orogenic event (historically called the 'Svalbardian event', Vogt [46]) is also well pronounced within the post-Caledonian Old Red molasse sediments which were faulted and folded in the Late Devonian. Also, the base of the post-Devonian sedimentary basin is marked by an angular unconformity reflecting postEllesmerian (post-Svalbardian) sedimentation.

The SBP clearly differs from the two other basement provinces of Svalbard. It records Stenian-Ectasian and latest Neoproterozoic mafic magmatism as well as Torellian and Ellesmerian metamorphism which are all unrecognized in the other basement provinces. In addition, it lacks evidence for high-temperature Late Caledonian migmatization and it does not comprise post-orogenic Caledonian granitic intrusions described from Northwestern and Northeastern provinces. A brief description of all magmatic and metamorphic events recorded within the SBP is given in more detail in the following paragraphs of this paper.

\section{Magmatic activity}

\section{Ectasian-Stenian magmatism}

The oldest igneous rocks within the SBP have been recognized in southern Wedel Jarlsberg Land. The basement block in which they occur is separated from the predominant low-grade metasediments of Wedel Jarlsberg Land by the Vimsodden-Kosibapasset shear zone, a strike-slip to oblique-slip, left-lateral crustal-scale structure (Fig. 1; see also Mazur et al. [35] for more details). Igneous rocks of Ectasian-Stenian age occur within the Eimfjellet Group, a unit dominated by various metaigneous rocks including granitoids, rhyolites, gabbros, basalts, mafic and felsic tuffs accompanied by metasedimentary quartzites and schists. The felsic and mafic rocks exhibit cross-cutting relationships, as metabasalts intrude granites and gabbros. These together are all cut by late aplitic dykes. All felsic varieties and gabbros have been dated using $\mathrm{U}-\mathrm{Pb}$ zircon evaporation technique and yielded uniform c. $1.20 \mathrm{Ga}$ age $[3,4]$. This age was confirmed by Larionov et al. [28], who dated several gabbros, granites and aplites that yielded $1.22-1.20 \mathrm{Ga}$ $\mathrm{U}-\mathrm{Pb}$ zircon ion microprobe ages.

\section{Tonian magmatism}

Tonian igneous rocks have only been recognized within the SBP at two localities thus far. One occurrence is located in the southern part of Oscar II Land and was described as an orthogneiss assigned to the Neoproterozoic St. Jonsfjorden Group, which otherwise consists of low-grade metasediments (Fig. 1). The rock has a felsic composition and yielded a $927 \pm 3 \mathrm{Ma}$ U-Pb TIMS zircon age [12]. Not much is known about its actual stratigraphic position and its relation to the surrounding metasediments, but it is thought to be tectonic in origin $[10,12]$. The second area where Tonian igneous rocks occur is located in Wedel Jarlsberg Land, south of Van Keulenfjorden and east of Recherchefjorden. A suite of pervasively tectonized augen gneiss occurs around the Antoniabreen on Martinfjella, Berzeliuseggene and Aldegondaberget ridges. These rocks were initially called the Berzeliuseggene Igneous Suite [32], while Dallmann et al. [10] preferred the informal name 'Berzeliuseggene unit'. Ion microprobe zircon $\mathrm{U}-\mathrm{Pb}$ dating yielded a $950 \pm 5 \mathrm{Ma}$ protolith crystallization age of the augen gneisses [32]. The Berzeliuseggene unit displays a tectonic contact with the Neoproterozoic Deilegga and Sofiebogen groups and other sediments of unknown, but probable Early Paleozoic age $[9,32,33]$. This contact has been interpreted as a rotated, large-scale sinistral shear zone, similar to the aforementioned Vimsodden-Kosibapasset zone [33].

\section{Cryogenian-Ediacaran magmatism}

Late Neoproterozoic magmatism is manifested by the occurrence of abundant mafic volcanics across the entire SBP. In Wedel Jarlsberg Land, a dyke swarm intrudes Early Neoproterozoic metasediments of the Deilegga Group, whereas volcanic equivalents of the dyke swarm (e.g. lavas and tuffs) are recognized within the overlying Late Neoproterozoic Sofiebogen Group (and correlative units; Fig. 1). These mafic rocks are commonly referred to as the Jens Erikfjellet Formation [8]. Their geochemical signature indicates a within-plate tholeiitic source $[8,17]$. In the northern part of Wedel Jarlsberg Land (Chamberlindalen area), a suite of well-preserved alkali cumulates is present [18]. These rocks are considered to have formed during the same event as the prevalent within-plate tholeiites in this area. The volcanics that occur in Wedel Jarlsberg Land have never been properly dated, although the age of the magmatic event is assumed to be c. 600 Ma based solely on the field relations, i.e. intercalations of lavas with the Ediacaran sediments. Farther 
north in Nordenskiöld Land, Oscar II Land and on Prins Karls Forland, mafic rocks occur in a similar tectonostratigraphic position (i.e. within Neoproterozoic sediments), but not much is known about their origin. The only set of geochemical data for greenstones from Oscar II Land has been published by Ohta [38], but the results were rather inconclusive. Whether or not all these mafic rocks belong to the same magmatic event is unknown, but nonetheless they represent the most voluminous magmatism within the SBP.

\section{Metamorphic events}

\section{Grenvillian Orogeny}

Traditionally, some parts of the SBP were thought to have undergone Grenvillian metamorphism (see e.g. [8]). This was based on early geochronological works providing rather questionable Early Neoproterozoic ages, which were interpreted to be metamorphic. Gavrilenko et al. [13] reported a whole rock $\mathrm{Rb}-\mathrm{Sr}$ age of c. $930 \mathrm{Ma}$ for the Isbjørnhamna Group, based on a three-point isochron, whereas Balashov et al. [3] dated zircon separated from the rhyolitic rocks of the Eimfjellet Group, using the traditional U-Pb whole grain technique, and obtained a lower intercept of concordia at $931 \pm 54 \mathrm{Ma}$. These age estimates were discredited by Majka et al. [29] and subsequent studies which highlighted methodological problems of the previous studies and presented new geochronological and geological evidence ruling out a possibility of Grenvillian metamorphism record in the Isbjørnhamna Group.

\section{Torellian Orogeny}

The first historical radiometric dating within the SBP was done by Gayer et al. [14], who dated the Isbjørnhamna Group using $\mathrm{K}-\mathrm{Ar}$ dating of dark mica and obtained ages of $556 \pm 24 \mathrm{Ma}$ and $584 \pm 25 \mathrm{Ma}$. This age was for a long time disregarded and thought to be possibly meaningless due to, e.g. excess ${ }^{40} \mathrm{Ar}$. About 30 years later, Manecki et al. [34] used the ${ }^{40} \mathrm{Ar} /{ }^{39} \mathrm{Ar}$ step heating technique to date separates of hornblende, muscovite and biotite from the Isbjørnhamna, Eimfjellet, Deilegga and Sofiebogen groups (Fig. 1). While most of the ages obtained were Caledonian (see below), some appeared to be Late Neoproterozoic. These Neoproterozoic ages were obtained from a hornblende separate from the Eimfjellet Group (616 $17 \mathrm{Ma}$, Fig. 2) and two muscovite separates from the Isbjørnhamna Group (575 \pm 15 and $584 \pm 14 \mathrm{Ma}$, Fig. 2). These authors suggested that the obtained ages reflected the latest Neoproterozoic re-heating and speculated that it might have been related to the opening of the early Iapetus Ocean. Majka et al. [29] dated metamorphic monazite in the Isbjørnhamna Group and obtained an age of $643 \pm 9 \mathrm{Ma}$ (Fig. 2). These authors linked the growth of the dated monazite with a regional amphibolite facies metamorphic event. They also re-interpreted the previous $\mathrm{K}-\mathrm{Ar}$ and ${ }^{40} \mathrm{Ar} /{ }^{39} \mathrm{Ar}$ dates as cooling ages after the amphibolite facies event. In addition, they also suggested that these dated metamorphic rocks on Svalbard might form a northwestern extension of the Timanide Orogen. This discovery was followed by further dating of different lithologies within the SBP. Majka et al. [31] dated zircon, monazite and uraninite in the Skoddefjellet pegmatite occurring within the Isbjørnhamna Group and obtained again Late Neoproterozoic ages: $651 \pm 88 \mathrm{Ma}$ for zircon, $675 \pm 25 \mathrm{Ma}$ for monazite and $685 \pm 5.5 \mathrm{Ma}$ for

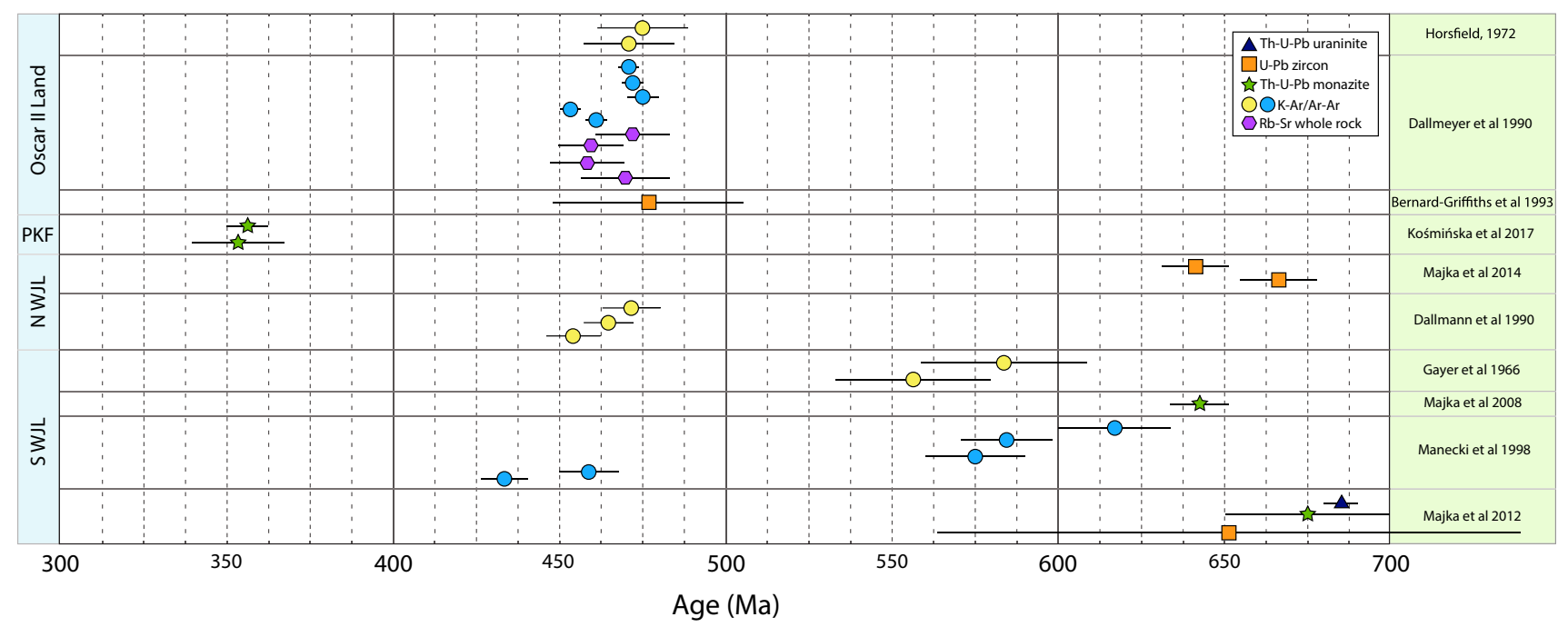

Fig. 2 Summary of the metamorphic ages for the Southwestern Basement Province. The radiometric methods as well as cited references are indicated on the diagram. PKF Prins Karls Forland, $N$ WJL northern Wedel Jarlsberg Land, $S$ WJL southern Wedel Jarlsberg Land 
uraninite, respectively (Fig. 2). They claimed that the Skoddefjellet pegmatite was the result of partial melting of the Isbjørnhamna Group metasediments. This study was followed by the aforementioned $\mathrm{U}-\mathrm{Pb}$ zircon dating of the Berzeliuseggene unit [32]. Zircon separated from augen gneisses displayed metamorphic zircon rim overgrowths on Tonianaged cores. These metamorphic rims yielded a $635 \pm 10 \mathrm{Ma}$ age (Fig. 2). Zircon from a pegmatite occurring within the Berzeliuseggene unit yielded an age of $665 \pm 11 \mathrm{Ma}$, corroborating the metamorphic rim ages. Regarding conditions of metamorphism, the Eimfjellet Group was subjected to upper greenschist to lower amphibolite facies conditions; however, these estimates are currently only based on petrographical observations of mineral assemblages (e.g. [8]). In contrast, the Isbjørnhamna Group and the Berzeliuseggene unit have been studied in detail with regard to pressure-temperature $(P-T)$ conditions using classical geothermobarometry and thermodynamic phase equilibria modeling. The maximum $P-T$ conditions for the Isbjørnhamna Group were estimated at $11 \mathrm{kbar}$ and $680{ }^{\circ} \mathrm{C}$ [30], whereas conditions for the Berzeliuseggene unit were constrained at $6 \mathrm{kbar}$ and $600{ }^{\circ} \mathrm{C}$ [33].

\section{Caledonian Orogeny}

The crystalline bedrock of the SBP was assembled during the Caledonian Orogeny. However, provided the extensiveness of Caledonian Orogeny throughout the SBP, there remains a significant lack of information regarding the exact timing and $P-T$ conditions of Caledonian tectonometamorphic events. The vast majority of the rock units within the SBP were subjected to (lower) greenschist facies metamorphism. However, locally some regions preserve record of HP metamorphism. In the southern part of Oscar II Land, the HP Vestgötabreen Complex crops out on Motalafjella, Skipperryggen and an unnamed nunatak north of the latter. The HP rocks are represented by carbonates, blueschists, eclogites and glaucophane-bearing metasediments accompanied by serpentinites. Available geochronological data suggest a c. $470 \mathrm{Ma}$ age of metamorphism based on $\mathrm{K}-\mathrm{Ar}$ muscovite dating [22], ${ }^{40} \mathrm{Ar} /{ }^{39} \mathrm{Ar}$ muscovite and paragonite dating ([11], Fig. 2), lower intercept of the U-Pb zircon discordia [5] as well as $\mathrm{Rb}-\mathrm{Sr}$ analyses [11]. The retrograde blueschists can be traced south of Oscar II Land in Nordenskiöld Land near Marvågen and Orustosen as shown by Kośmińska et al. [25]. Also, the polymetamorphic rocks of the Berzeliuseggene unit are overprinted by the HP metamorphic event of inferred Caledonian age $([9,33]$ and references therein). The only reliable ages derived for the greenschist facies rocks come from the southern part of Wedel Jarlsberg Land and have been published by Manecki et al. [34]. These authors reported on the ${ }^{40} \mathrm{Ar} /{ }^{39} \mathrm{Ar}$ plateau ages of $432 \pm 7 \mathrm{Ma}$ for a muscovite-carbonate-quartz schist of the Sofiebogen Group and of $459 \pm 9$ Ma for a muscovite schist of the Eimfjellet
Group. The former age can be interpreted as a Late Caledonian greenschists facies overprint, whereas the latter has been interpreted by Mazur et al. [35] to reflect the activity of the Vimsodden-Kosibapasset Shear Zone, because the muscovite schist sensu [34] is in fact a mylonite parallel with the main shear zone. Not much is known about the exact $P-T$ conditions of the greenschist facies metamorphism, whereas the HP rocks have been the subject of more detailed studies. Pioneering work by Hirajima et al. [21] on eclogites from the Vestgötabreen Complex suggested that these rocks were clearly metamorphosed in a subduction regime at $18-24 \mathrm{kbar}$ by $580-640{ }^{\circ} \mathrm{C}$. Agard et al. [1] reported on a discovery of carpholite-bearing schists from that region and demonstrated that they were metamorphosed under conditions of 15-16 kbar and $380-400{ }^{\circ} \mathrm{C}$. These authors also showed that parts of the Vestgötabreen Complex were subducted at a low c. $7{ }^{\circ} \mathrm{C} / \mathrm{km}$ geothermal gradient. Retrograde blueschists from Nordenskiöld Land yielded $P-T$ conditions of $14-18$ kbar by $470-490{ }^{\circ} \mathrm{C}$ and confirmed a low $7-8{ }^{\circ} \mathrm{C} / \mathrm{km}$ subduction gradient [25]. Majka et al. [33] have reported on 9-12 kbar and c. $500-550{ }^{\circ} \mathrm{C} P-T$ conditions for the Caledonian metamorphic overprint of the Berzeliuseggene unit.

\section{Ellesmerian (Svalbardian) Orogeny}

Amphibolite facies metamorphism of Ellesmerian age was recently documented for rocks of the Pinkie unit, which crop out on Prins Karls Forland (Grimaldibukta area). This unit represents the highest grade of rocks on Prins Karls Forland that are separated from surrounding units by tectonic contacts. The Pinkie unit comprises quartzites with carbonate-rich laminae in the lower part of the tectonostratigraphic profile and garnet-bearing metapelites with staurolite and kyanite in the highest part. The age of the protolith is poorly constrained. Preliminary detrital zircon dating from the Pinkie unit quartzite shows U-Pb ages as young as $950 \mathrm{Ma}$ [26]. Monazite from garnet-bearing metapelites yielded the ages of $359 \pm 6$ to $355 \pm 14$ Ma ([27]; Fig. 2). Kośmińska et al. [27] proposed an anticlockwise $P-T$ path for those rocks and suggested that the garnet-bearing metapelites were formed under the conditions of c. $7-10 \mathrm{kbar}$ and $550-650{ }^{\circ} \mathrm{C}$, followed by late mylonitization at approximately $10 \mathrm{kbar}$ and $500^{\circ} \mathrm{C}$.

\section{Final remarks}

The SBP reveals a composite structure and comprises several tectonic units juxtaposed by major strike-slip and thrust zones of varying age, from Early Paleozoic (perhaps also Neoproterozoic) to Paleogene. It differs substantially from the Northeastern and Northwestern provinces that contain voluminous Tonian igneous rocks intruding Mesoproterozoic sediments [16, 23, 39] that are locally 
unconformably overlain by calc-alkaline volcanics (where the record is still preserved) and a continuous sequence of Neoproterozoic to Paleozoic sediments (e.g. [44]). As previously mentioned, Late Caledonian migmatization is a common phenomenon in both the Northeastern and Northwestern basement provinces (e.g. [37, 40, 41, 45]), whereas Caledonian migmatites lack the SBP. Similarly, the occurrence of Late Caledonian post-orogenic granites is limited to the Northeastern and Northwestern provinces (e.g. [24, 41]). Additionally, the Northeastern Province comprises c. $1735 \mathrm{Myr}$ old granites (e.g. [47]), whereas the Northwestern Province bears a record of HP metamorphism of Caledonian age [19]. The latter indicates that at least this part of the Northwestern Province may share some similarities with the SBP, but the majority of it is completely different. The relative similarities between the two northern provinces, as briefly characterized above, compared to the SBP, which preserves a clearly different composition and tectonothermal history, suggests that the SBP is (at least partially) exotic in origin.

Recent discoveries of previously completely unknown Tonian, Cryogenian and Devonian magmatic and metamorphic rocks in the SBP emphasize that little is currently known about the evolution of this key basement area of Svalbard. A multitude of important questions still remain to be answered. How widespread is the Tonian magmatism? Did the Torellian event affect the majority of the Caledonian bedrock of the SBP? Was this event indeed related to the Timanian Orogeny of northeastern Baltica? What is the relationship between the Torellian event and the recently discovered age-equivalent arc-related rocks in northern Greenland [42]? How widespread is the HP Vestgötabreen Complex, and can an Early Caledonian suture zone be traced along the occurrences? Was there any Caledonian tectonometamorphic activity that occurred in post-Ordovician time (there is no geochronological evidence for such events)? Can we expect more Ellesmerian metamorphic rocks within the SBP? Is the SBP a true counterpart of the Pearya Terrane of northern Ellesmere Island? These are the most prominent questions to be answered for the Southwestern Basement Province, yet they do not represent the full spectrum of issues that still require attention. To reconcile these problems, it is clear that many more field campaigns and comprehensive pressure-temperature-time-deformation studies must be carried out. Optimistically, the lack of research and resulting lack of geological knowledge regarding the Southwestern Basement Province presents a plethora of research opportunities that are awaiting the future work of geoscientists. A prime example of such opportunity is the thick crystalline succession just south of the easily accessible Ny Ålesund research settlement that has never been studied by means of petrology and geochronology. Lastly, the authors of this contribution want to stress that they hope this short review will be rendered obsolete by future research as soon as possible.

Acknowledgements Winfried Dallmann, David G. Gee and an anonymous reviewer are thanked for their comments on this paper. Chris Barnes is acknowledged for fruitful discussions and linguistic help. This review is vastly based on the results obtained in connection with several expeditions organized by AGH University of Science and Technology (Kraków, Poland), Norwegian Polar Institute and Uppsala University (Sweden). Financial support of the National Science Centre (Poland) through the Project nos. 2013/11/N/ST10/00357 and 2015/17/B/ST10/03114 is also acknowledged.

Open Access This article is distributed under the terms of the Creative Commons Attribution 4.0 International License (http://creativecommons.org/licenses/by/4.0/), which permits unrestricted use, distribution, and reproduction in any medium, provided you give appropriate credit to the original author(s) and the source, provide a link to the Creative Commons license, and indicate if changes were made.

\section{References}

1. Agard P, Labrousse L, Elvevold S, Lepvrier C (2005) Discovery of Palaeozoic Fe-Mg carpholite (Motalafjella, Svalbard Caledonides): a milestone for subduction zone gradients. Geology 33:761-764

2. Armstrong HA, Nakrem HA, Ohta Y (1986) Ordovician conodonts from the Bulltinden Formation, Motalafjella, central-western Spitsbergen. Polar Res 4:17-23

3. Balashov YA, Tebenkov AM, Ohta Y, Larionov AN, Sirotkin AN, Gannibal LF, Ryungenen GI (1995) Grenvillian U-Pb zircon ages of quartz porphyry and rhyolite clasts in a metacoglomerate at Vimsodden, southern Spitsbergen. Polar Res 14:291-302

4. Balashov YA, Tebenkov AM, Peucat JJ, Ohta Y, Larionov AN, Sirotkin AN (1996) Rb-Sr whole rock and U-Pb zircon dating of the granitic-gabbroic rocks from the Skålfjellet Subgroup, southwest Spitsbergen. Polar Res 15:167-181

5. Bernard-Griffiths J, Peucat JJ, Ohta Y (1993) Age and nature of protoliths in the Caledonian blueschist-eclogite complex of western: a combined approach using $\mathrm{U}-\mathrm{Pb}, \mathrm{Sm}-\mathrm{Nd}$ and $\mathrm{REE}$ wholerock systems. Lithos 30:81-90

6. Birkenmajer K (1975) Caledonides of Svalbard and plate tectonics. Bull Geol Soc Den 24:1-19

7. Bjørnerud M (1990) Upper Proterozoic unconformity in northern Wedel-Jarlsberg Land, southwest Spitsbergen: lithostratigrapby and tectonic implications. Polar Res 8:127-140

8. Czerny J (1999) Petrogenesis of metavolcanites of the southern part of Wedel Jarlsberg Land (Spitsbergen). Prace Mineralogiczne 86, Kraków: Wydawnictwo Oddziału PAN, pp 1-88

9. Dallmann WK, Hjelle A, Ohta Y, Salvigsen O, Maher HD, Bjørnerud M, Hauser EC, Craddock C (1990) Geological map of Svalbard 1:100,000, B11G Van Keulenfjorden. Nor. Polarinst. Temakart No. 15

10. Dallmann WK, Elvevold S, Majka J, Piepjohn K (2015) Chap. 8: tectonics and tectonothermal events. In: Dallmann WK (ed) Geoscience Atlas of Svalbard. Nor Polarinst Rapportserie 148, Troms $\varnothing$, pp 175-220

11. Dallmeyer RD, Peucat JJ, Hirajima T, Ohta Y (1990) Tectonothermal chronology within a blueschist-eclogite complex, west-central Spitsbergen, Svalbard: evidence from ${ }^{40} \mathrm{Ar} /{ }^{39} \mathrm{Ar}$ and $\mathrm{Rb} / \mathrm{Sr}$ mineral ages. Lithos 24:291-304 
12. Gasser D, Andresen A (2013) Caledonian terrane amalgamation of Svalbard: detrital zircon provenance of Mesoproterozoic to Carboniferous strata from Oscar II Land, western Spitsbergen. Geol Mag 150:1103-1126

13. Gavrilenko BV, Balashov JUA, Tebenkov AM, Larionov AN (1993) U-Pb early Proterozoic age of "relict" zircon from high potassium quartzose porphyries of Wedel Jarlsberg Land, SW Spitsbergen. Geochimija 1:154-158

14. Gayer RA, Gee DG, Harland WB, Miller JA, Spall HR, Wallis RH, Winsnes TS (1966) Radiometric age determinations on rocks from Spitsbergen. Nor Polarinst Skr 137:1-39

15. Gee DG, Tebenkov AM (2004) Svalbard: a fragment of the Laurentian margin. In: Gee DG, Pease V (eds) The Neoproterozoic Timanide Orogen of eastern Baltica, vol 30. The Geological Society of London, London, pp 191-206

16. Gee DG, Johansson $\AA$, Ohta Y, Tebenkov AM, Krasil'scikov AA, Balashov YuA, Larionov AN, Gannibal LF, Ryungenen GF (1995) Grenvillian basement and a major unconformity within the Caledonides of Nordaustlandet, Svalbard. Precambr Res 70:215-234

17. Gołuchowska K, Barker AK, Majka J, Manecki M, Czerny J, Bazarnik J (2012) Preservation of magmatic signals in metavolcanics from Wedel Jarlsberg Land, SW Svalbard. Mineralogia 43:179-197

18. Gołuchowska K, Barker AK, Czerny J, Majka J, Manecki M, Farajewicz M, Dwornik M (2016) Magma storage of an alkali ultramafic igneous suite from Chamberlindalen, SW Svalbard. Mineral Petrol 110(5):623-638

19. Gromet LP, Gee DG (1998) An evaluation of the age of highgrade metamorphism in the Caledonides of Biskayerhalvøya. GFF 120:199-208

20. Harland WB, Cutbill JL, Friend PF, Gobbett DJ, Holliday DW, Maton P, Parker JR, Wallis RH (1974) The Billefjorden fault zone, Spitsbergen. The long history of a major tectonic lineament. Nor Polarinst Skr 161:1-72

21. Hirajima T, Banno S, Hiroi Y, Ohta Y (1988) Phase petrology of eclogites and related rocks from the Motalafjella high-pressure metamorphic complex in Spitsbergen (Arctic Ocean) and its significance. Lithos 22:75-97

22. Horsfield WT (1972) Glaucophane schists of Caledonian age from Spitsbergen. Geol Mag 109:29-36

23. Johansson $\AA$, Larionov AN, Tebenkov AM, Gee DG, Whitehouse MJ, Vestin J (2000) Grenvillian magmatism of western and central Nordaustlandet, northeastern Svalbard. Trans R Soc Edinb Earth Sci 90:221-254

24. Johansson A, Larionov AN, Tebenkov AM, Ohta Y, Gee DG (2002) Caledonian granites of western and central Nordaustlandet, northeast Svalbard. GFF 124:135-148

25. Kośmińska K, Majka J, Mazur S, Krumbholz M, Klonowska I, Manecki M, Czerny J, Dwornik M (2014) Blueschist facies metamorphism in Nordenskiöld Land of west-central Svalbard. Terra Nova 26(5):377-386

26. Kośmińska K, Schneider DA, Majka J, Lorenz H, Gee DG, Manecki M, Barnes C (2015) Detrital zircon U-Pb geochronology of metasediments from southwestern Svalbard's Caledonian Province. EGU European geosciences union: general assembly 2015: Vienna, Austria, 12-17 April 2015

27. Kośmińska K, Majka J, Spear FS (2017) P-T-t metamorphic evolution of highly deformed metapelites from the Pinkie unit of western Svalbard using quartz-in-garnet barometry, trace element thermometry, P-T-X-M diagrams and monazite in-situ dating. EGU European Geosciences Union: general assembly 2017: Vienna, Austria, 23-28 April 2017

28. Larionov AN, Tebenkov AM, Gee DG, Czerny J, Majka J (2010) Recognition of Precambrian tectonostratigraphy in Wedel-Jarlsberg Land, southwestern Spitsbergen. In: Abstract and proceedings of the geological society of Norway, NGF, pp 106
29. Majka J, Mazur S, Manecki M, Czerny J, Holm DK (2008) Late Neoproterozoic amphibolite-facies metamorphism of a pre-Caledonian basement block in southwest Wedel Jarlsberg Land, Spitsbergen: new evidence from $\mathrm{U}-\mathrm{Th}-\mathrm{Pb}$ dating of monazite. Geol Mag 145:822-830

30. Majka J, Czerny J, Mazur S, Holm DK, Manecki M (2010) Neoproterozoic metamorphic evolution of the Isbjørnhamna Group rocks from south-western Svalbard. Polar Res 29:250-264

31. Majka J, Larionov AN, Gee DG, Czerny J, Pršek J (2012) Neoproterozoic pegmatite from Skoddefjelet, Wedel Jarlsberg Land, Spitsbergen: additional evidence for c. $640 \mathrm{Ma}$ tectonothermal event in the Caledonides of Svalbard. Pol Polar Res 33:1-17

32. Majka J, Be'eri-Shlevins Y, Gee DG, Czerny J, Frei D, Ladenberger A (2014) Torellian (c.640 Ma) metamorphic overprint of Tonian (c. $950 \mathrm{Ma}$ ) basement in the Caledonides of southwestern Svalbard. Geol Mag 151:732-748

33. Majka J, Kośmińska K, Mazur S, Czerny J, Piepjohn K, Dwornik M, Manecki M (2015) Two garnet growth events in polymetamorphic rocks in southwest Spitsbergen, Norway: insight in the history of Neoproterozoic and early Paleozoic metamorphism in the High Arctic. Can J Earth Sci 52(12):1-17

34. Manecki M, Holm DK, Czerny J, Lux D (1998) Thermochronological evidence for late Proterozoic (Vendian) cooling in southwest Wedel Jarlsberg Land, Spitsbergen. Geol Mag 135:63-69

35. Mazur S, Czerny J, Majka J, Manecki M, Holm D, Smyrak A, Wypych A (2009) A strike-slip terrane boundary in Wedel Jarlsberg Land, Svalbard, and its bearing on correlations of SW Spitsbergen with the Pearya terrane and Timanide belt. J Geol Soc Lond 166:529-544

36. Ohta Y (1975) Blue schists from Motalafjella, western Spitsbergen. Nor Polarinst Skr 167:171-217

37. Ohta Y (1982) Lithostratigraphy of the Hecla Hoek rocks in central Nordaustlandet and their relationships to the Caledonian granitic-migmatitic rocks. Nor Polarinst Skr 178:41-60

38. Ohta Y (1985) Geochemistry of Precambrian basic igneous rocks between St. Jonsfjorden and Isfjorden, central western Spitsbergen, Svalbard. Polar Res 3:49-67

39. Ohta $\mathrm{Y}$, Larionov AM (1998) Grenvillian single grain zircon $\mathrm{Pb}$ age of granitic rock from the southern island of Hesteskoholmen, Liefdefjorden, NWSpitsbergen. Polar Res 17:147-154

40. Ohta Y, Larionov AN, Tebenkov AM, Lepvrier C, Maluski H, Lange M, Hellibrant B (2002) Single zircon Pb-evaporation and $40^{\mathrm{Ar}}{ }^{39} \mathrm{Ar}$ dating of the metamorphic and granitic rocks in northwest Spitsbergen. Polar Res 21:73-89

41. Pettersson CH, Tebenkov AM, Larionov AN, Andresen A, Pease V (2009) Timing of migmatization and granite genesis in the Northwestern Terrane of Svalbard, Norway-implications for regional correlations in the Arctic Caledonides. J Geol Soc Lond 166:147-158

42. Rosa D, Majka J, Thrane K, Guarnieri P (2016) Evidence for Timanian-age basement rocks in North Greenland as documented through $\mathrm{U}-\mathrm{Pb}$ zircon dating of igneous xenoliths from the Midtkap volcanic centers. Precambr Res 275:394-405

43. Scrutton CT, Horseield WT, Harland WB (1976) Silurian fossils from western Spitsbergen. Geol Mag 113:519-523

44. Tebenkov AM (1983) Late Precambrian magmatic formations of Nordaustlandet. In: Krasilshikov AA, Basovs VA (eds) The geology of Spitsbergen: a collection of papers. Sevmorgeo, Leningrad, pp 74-86

45. Tebenkov AM, Sandelin S, Gee DG, Johansson A (2002) Caledonian migmatization in central Nordaustlandet, Svalbard. Nor Polarinst Skr 82(2): 15-28

46. Vogt T (1929) Den norske fjellkjedes revolusjonshistorie. Nor Polarinst Skr 10:97-115

47. Witt-Nilsson P, Gee DG, Hellman FJ (1998) Tectonostratigraphy of the Caledonian Atomfjella Antiform of northern Ny Friesland, Svalbard. Nor Polarinst Skr 78:67-80 